\title{
Spatial Differentiation of Tax Collection Costs in Poland
}

\author{
Lukasz FURMAN*, Paulina KOZA \\ Carpathian State University, Krosno, Poland; lukasz.furman@kpu.krosno.pl; paulinakoza19@gmail.com \\ * Corresponding author: lukasz.furman@kpu.krosno.pl
}

\begin{abstract}
The article was devoted to presenting the concept of the cost of collecting taxes, which are borne by the state. The article discusses the division of this cost according to the type system of costs, which functions in accounting. The division of costs by type distinguishes the costs of consumption of materials and energy, depreciation of tangible and intangible assets, external services, social insurance and other employee benefits, taxes and fees and other costs. These costs are incurred by tax offices and customs and fiscal offices involved in tax collection in Poland. In each province tax collection is supervised by tax administration chambers, which determine at the provincial level the total cost of collection. These are the total costs incurred by tax offices, customs and tax administration offices and tax administration chambers. In the course of writing the article, a hypothesis was put forward: there is a variation in the cost of tax collection within individual provinces in Poland. To verify the hypothesis, the method of analyzing statistical data consisting of annual total tax receipts and annual total costs by type was used. The study covered the period from 2015 to 2019.
\end{abstract}

Keywords: tax collection cost; cost by nature; tax receipts; tax administration

JEL Classification: $\mathrm{H} 20 ; \mathrm{H} 21$

\section{Introduction}

The issue of tax collection costs is a concept that is closely related to the functioning of the public finance sector. In any market economy, the state influences the economy to some extent through various methods. A certain instrument is the tax system, which allows accumulating public revenues. This fulfills the fiscal function. The state, while collecting public levies, must have worked out the principles of their collection and appropriate infrastructure facilities with employees. Tax collection results in costs on the part of the state or local government (as institutions authorized to collect taxes). This topic is extremely broad because some costs associated with tax collection already arise in the legislation of tax laws. The final stage, where the costs of collection occur, is the enforcement of the tax when the taxpayer voluntarily fails to pay the tax.

Thus, the purpose of this article is to present the concept of cost of tax collection and its various aspects presented in the literature. In the article it was also decided to verify the hypothesis which reads: in individual provinces of Poland there is a variation in the cost of tax collection. Both domestic and foreign literature was used in writing the article. 


\section{Methodology}

As it was mentioned in the introduction, the paper decided to verify the hypothesis that there is a differentiated cost of tax collection in 16 voivodeships in Poland. A Statistical data analysis method was used to reject or confirm the hypothesis. For statistical analysis, the following data were obtained: On the amount of generic costs incurred by the institutions collecting taxes in each province for the state budget. On the amount of taxes collected for the state budget in each province. The time period of the study was from 2015 to 2019.

\section{Concept of the Principle of Low-Cost Tax Collection}

The costs of tax collection have already been recognized by classical economists. Adam Smith in his work commented on the tax system in tax principles. One of those rules was specifically about the rules for collecting taxes. He wrote that in collecting taxes the state should keep in mind the principle of cheapness. It indicated that tax collection should be done at the lowest possible cost. This is especially true for a state that collects taxes. Other principles he created are the principle of equality, the principle of certainty and the principle of convenience. However, when analyzing the cost system of tax collection from the point of view of the tax collector than the principle of cheapness becomes the most important (Smith, 2012).

Subsequent economists developed the tax principles introduced by Adam Smith. In the nineteenth century A. Wagner, referring to the classical principles of taxation, observed that the principle of cheapness should concern the tax collector and the taxpayer. This resolution of the case takes into account the interests of both parties (Sosnowski, 2012).

Nor has the cheapness of the tax collection system lost its relevance in the economic realities of the 21st century. Economists continue to confirm that it is a guiding principle that should be taken into account by authorities legislating on public tributes. Such a solution is primarily based on the effectiveness of the public finance sector (Nowak, 2007a). In foreign publications we read about it, among others. in publications by Turner et al. (1998).

In Polish publications we can find references to the feature of cheapness of the tax collection system. It is visible especially in publications of N. Gajl, S. Owsiak, J. Głuszewski, W. Matuszewski, E. Małecka-Ziembińska. M. Kosek-Wojnar, K. Surówka, T. Famulska. These authors recognized that a feature of modern economy is the pursuit of its efficiency. The public finance sector should present appropriate solutions to economic realities - including a well-functioning tax collection system, which should pay attention to the costs of its functioning (Nowak, 2007b).

An interesting analysis of the principles of tax collection was presented by Franek and Adamczyk (2017). Among the existing principles, particular attention has been paid to the principle of cheapness, which is assessed in different tax systems using specific metrics. Most commonly, it is a measure defined as the ratio of the cost of operating a tax administration to the tax revenue generated in a country (Franek \& Adamczyk, 2017). 
The tax collection process evolves in every economy. The public administration, including tax administration, is increasingly computerized, which was noticed by, among others by Żak (2011).

\section{Discussion}

The subject related to the functioning of the principle of cheapness of tax collection was decided to check on the example of empirical data coming from the Polish tax administration, which functions in each of 16 voivodeships. The structure of this administration consists of: 16 fiscal administration chambers, 400 fiscal offices, 16 customs and fiscal offices. The chambers of fiscal administration are institutions that supervise the functioning of fiscal offices and customs and fiscal offices. Tax offices, on the other hand, collect both direct and indirect taxes from taxpayers. These taxes include, among others: personal income tax, corporate income tax, value added tax, excise tax, gaming tax, tonnage tax, tax on certain financial institutions, tax on civil law transactions, inheritance and donation tax.

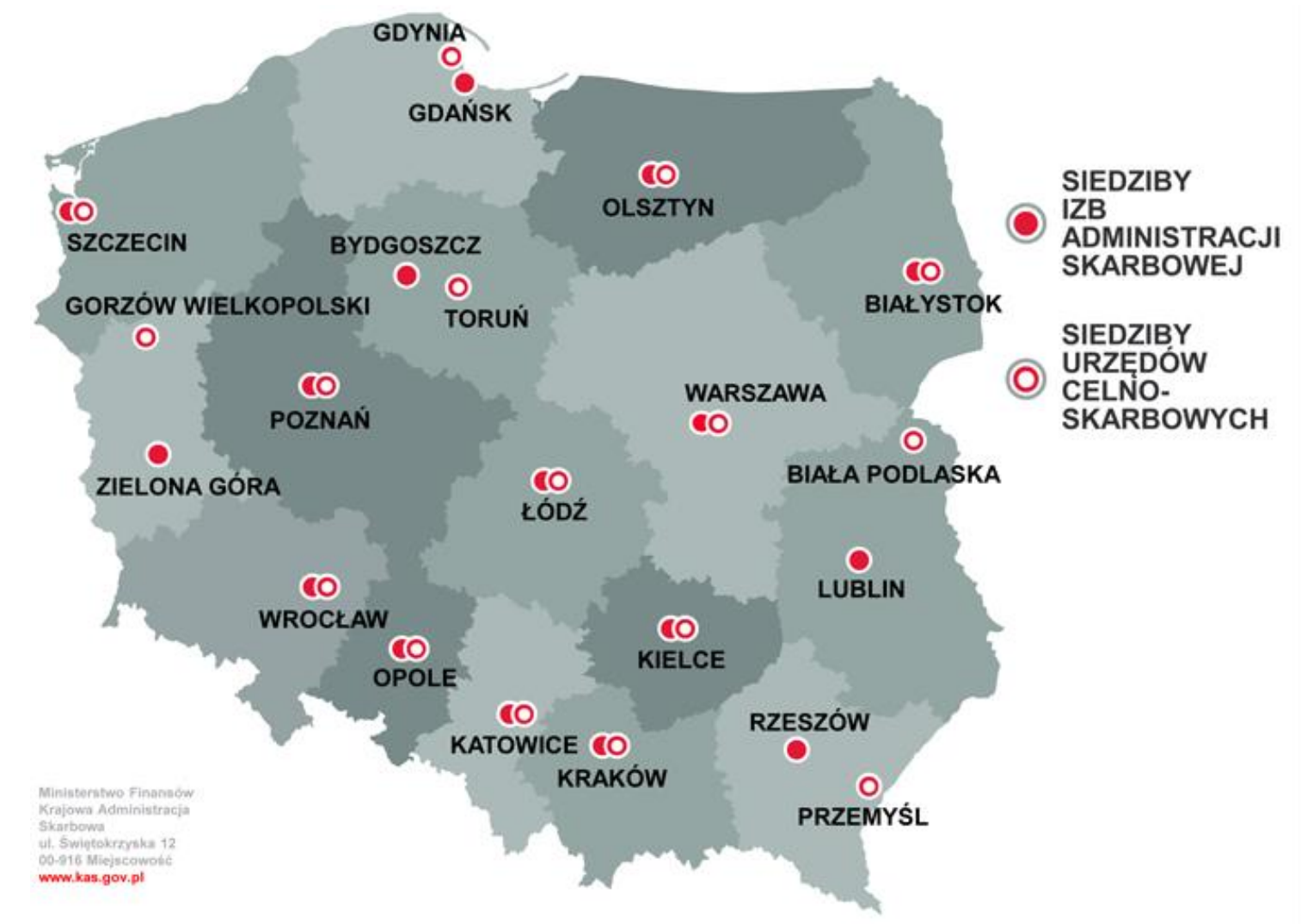

Figure 1. Territorial division of the National Tax Administration Units in Poland. (Source: https://www.gov.pl/web/kas/struktura-kas)

In turn, the customs and tax offices collect customs duty, import VAT resulting from customs declarations, domestic excise tax, excise tax on intra-Community acquisitions, import excise tax, tax on gaming, tax on extraction of certain minerals, VAT on intraCommunity acquisitions of motor fuels, amounts representing the value of excise tax stamps, duties on legalization of excise tax stamps. 
These tax administration units are financed directly from the state budget. In each province, records of the amount of taxes collected and the amount of costs incurred for operation are kept by the chamber of tax administration. Thanks to its accounting records, it is able to control the amount of costs incurred, as mentioned in the article by Furman (2011). Costs incurred by type refer to reporting periods, which are calendar years. Due to legal regulations, entities of the public finance sector in Poland are obliged to record them on an annual basis. Costs incurred by type include depreciation of tangible and intangible assets, consumption of materials and energy, external services, salaries, social security and other employee benefits, taxes and fees, other costs by type (Konopka, 2021).

Table 1. Total costs by type incurred by Tax Administration Chambers in individual provinces in 2015-2019 (in PLN million) (Source: Tax administration chambers by voivodeship)

\begin{tabular}{|c|c|c|c|c|c|c|}
\hline Lp. & Voivodeship & $\mathbf{2 0 1 5}$ & $\mathbf{2 0 1 6}$ & $\mathbf{2 0 1 7}$ & $\mathbf{2 0 1 8}$ & $\mathbf{2 0 1 9}$ \\
\hline $\mathbf{1 .}$ & Dolnośląskie & $\mathbf{2 2 5 . 5}$ & $\mathbf{2 8 9 . 1}$ & 410.7 & 430.3 & 472.1 \\
\hline $\mathbf{2 .}$ & Kujawsko-pomorskie & $\mathbf{1 8 4 . 1}$ & 187.9 & 254.2 & 263.2 & 297.5 \\
\hline $\mathbf{3 .}$ & Lubelskie & 29.6 & 159.3 & 357.4 & 372.3 & 415.9 \\
\hline $\mathbf{4 .}$ & Lubuskie & $\mathbf{7 9 . 7}$ & 100.5 & 186.5 & 197.6 & 221.1 \\
\hline $\mathbf{5 .}$ & Łódzkie & 203.6 & 257.5 & 347.6 & 370.3 & 408.6 \\
\hline $\mathbf{6 .}$ & Małopolskie & 225.9 & 290.0 & 429.6 & 452.2 & 499.3 \\
\hline $\mathbf{7 .}$ & Mazowieckie & 446.7 & 574.5 & 799.7 & 841.7 & 930.9 \\
\hline $\mathbf{8 .}$ & Oppolskie & 65.9 & 90.7 & 136.7 & 169.7 & 196.3 \\
\hline $\mathbf{9 .}$ & Podkarpackie & 137.8 & 141.7 & 282.6 & 294.4 & 331.4 \\
\hline $\mathbf{1 0 .}$ & Podlaskie & 68.4 & 87.2 & 208.2 & 222.4 & 248.2 \\
\hline $\mathbf{1 1 .}$ & Pomorskie & 166.0 & 208.0 & 329.8 & 340.1 & 379.1 \\
\hline $\mathbf{1 2 .}$ & Śląskie & 351.5 & 446.7 & 572.7 & 604.4 & 678.7 \\
\hline $\mathbf{1 3 .}$ & Świętokrzyskie & 90.5 & 94.8 & 125.3 & 136.1 & 150.6 \\
\hline $\mathbf{1 4 .}$ & Warmińsko-mazurskie & 85.9 & 109.9 & 213.1 & 216.1 & 240.8 \\
\hline $\mathbf{1 5 .}$ & Wielkopolskie & 345.9 & 350.4 & 457.0 & 478.6 & 528.9 \\
\hline $\mathbf{1 6 .}$ & Zachodnio- pomorskie & 139.9 & 180.3 & 278.9 & 290.1 & 323.5 \\
\hline
\end{tabular}

In the data presented in Table 1, it can be seen what the sum of generic costs of the Administrative and Tax Chamber is in the province in 2015-2019. The dominant cost in each province is salaries. It is one of the main costs occupying the largest percentage in the generic costs. An upward trend in costs by type can be observed from year to year. The highest sum of incurred generic costs in 2015 was recorded in the Mazowieckie Voivodeship, while the lowest in the Świętokrzyskie Voivodeship. Taxes and charges have the lowest share of costs by type in each province.

The data presented in Table 2 show that the highest tax revenue is generated by the Mazowieckie voivodeship. In 2019, we may see a decrease in receipts in Lubuskie County, which can be explained by increased tax refunds. Mazowieckie and Małopolska are the richest regions of the country in terms of tax revenue. 
Table 2. Total taxes collected in each province in 2015-2019 (in PLN million) (Source: Tax administration chambers by voivodeship)

\begin{tabular}{|c|c|c|c|c|c|c|}
\hline Lp. & Voivodeship & $\mathbf{2 0 1 5}$ & $\mathbf{2 0 1 6}$ & $\mathbf{2 0 1 7}$ & $\mathbf{2 0 1 8}$ & $\mathbf{2 0 1 9}$ \\
\hline $\mathbf{1 .}$ & Dolnośląskie & $\mathbf{1 5 , 2 8 8 . 7}$ & $\mathbf{1 6 , 2 8 7 . 8}$ & $22,178.4$ & $23,098.8$ & $22,998.8$ \\
\hline $\mathbf{2 .}$ & Kujawsko-pomorskie & $5,648.2$ & $\mathbf{6 , 9 7 3 . 8}$ & $7,692.0$ & $9,025.0$ & $9,841.2$ \\
\hline $\mathbf{3 .}$ & Lubelskie & $5,325.4$ & $5,407.3$ & $6,388.0$ & $6,773.6$ & $7,203.6$ \\
\hline $\mathbf{4 .}$ & Lubuskie & $1,625.8$ & $1,408.2$ & $2,067.7$ & $2,291.9$ & $1,997.4$ \\
\hline $\mathbf{5 .}$ & Łódzkie & $13,040.6$ & $14,510.3$ & $17,146.2$ & $19,116.5$ & $19,597.6$ \\
\hline $\mathbf{6 .}$ & Małopolskie & $18,170.2$ & $19,051.4$ & $96,429.1$ & $90,974.7$ & $93,182.0$ \\
\hline $\mathbf{7 .}$ & Mazowieckie & $92,099.1$ & $104,096.9$ & $124,347.7$ & $129,753.4$ & $138,950.2$ \\
\hline $\mathbf{8 .}$ & Opolskie & $3,772.8$ & $4,419.0$ & $5,464.7$ & $5,884.4$ & $6,216.7$ \\
\hline $\mathbf{9 .}$ & Podkarpackie & $5,096.7$ & $5,356.2$ & $7,243.2$ & $8,304.4$ & $8,198.6$ \\
\hline $\mathbf{1 0 .}$ & Podlaskie & $2,449.7$ & $2,559.9$ & $3,681.3$ & $3,863.1$ & $4,257.6$ \\
\hline $\mathbf{1 1 .}$ & Pomorskie & $13,408.9$ & $15,477.2$ & $17,536.9$ & $20,962.2$ & $23,434.4$ \\
\hline $\mathbf{1 2 .}$ & Śląskie & $20,477.0$ & $21,523.5$ & $27,941.7$ & $32,471.2$ & $35,669.5$ \\
\hline $\mathbf{1 3 .}$ & Świętokrzyskie & $2,570.3$ & $2,925.0$ & $3,458.9$ & $3,882.4$ & $4,467.3$ \\
\hline $\mathbf{1 4 .}$ & Warmińsko-mazurskie & $2,732.7$ & $2,579.8$ & $3,643.9$ & $4,003.0$ & $4,166.2$ \\
\hline $\mathbf{1 5 .}$ & Wielkopolskie & $23,017.8$ & $24,589.2$ & $28,922.3$ & $32,093.0$ & $34,337.4$ \\
\hline $\mathbf{1 6 .}$ & Zachodnio-pomorskie & $4,546.7$ & $4,695.5$ & $4,903.9$ & $5,518.2$ & $6,368.3$ \\
\hline
\end{tabular}

Table 3. Dynamics of generic costs incurred by Tax Administration Chambers in individual provinces in 2015-2019 in \% (Source: Tax administration chambers by voivodeship)

\begin{tabular}{|c|c|c|c|c|c|c|}
\hline Lp. & Voivodeship & $\mathbf{2 0 1 5}$ & $\mathbf{2 0 1 6}$ & $\mathbf{2 0 1 7}$ & $\mathbf{2 0 1 8}$ & $\mathbf{2 0 1 9}$ \\
\hline $\mathbf{1 .}$ & dolnośląskie & $100 \%$ & $128 \%$ & $142 \%$ & $105 \%$ & $110 \%$ \\
\hline $\mathbf{2 .}$ & kujawsko-pomorskie & $100 \%$ & $102 \%$ & $135 \%$ & $104 \%$ & $113 \%$ \\
\hline $\mathbf{3 .}$ & lubelskie & $100 \%$ & $539 \%$ & $224 \%$ & $104 \%$ & $224 \%$ \\
\hline $\mathbf{4 .}$ & lubuskie & $100 \%$ & $126 \%$ & $186 \%$ & $106 \%$ & $112 \%$ \\
\hline $\mathbf{5 .}$ & łódzkie & $100 \%$ & $126 \%$ & $135 \%$ & $107 \%$ & $110 \%$ \\
\hline $\mathbf{6 .}$ & małopolskie & $100 \%$ & $128 \%$ & $148 \%$ & $105 \%$ & $110 \%$ \\
\hline $\mathbf{7 .}$ & mazowieckie & $100 \%$ & $129 \%$ & $139 \%$ & $105 \%$ & $111 \%$ \\
\hline $\mathbf{8 .}$ & opolskie & $100 \%$ & $138 \%$ & $151 \%$ & $124 \%$ & $116 \%$ \\
\hline $\mathbf{9 .}$ & podkarpackie & $100 \%$ & $103 \%$ & $199 \%$ & $104 \%$ & $113 \%$ \\
\hline $\mathbf{1 0 .}$ & podlaskie & $100 \%$ & $128 \%$ & $239 \%$ & $107 \%$ & $112 \%$ \\
\hline $\mathbf{1 1 .}$ & pomorskie & $100 \%$ & $125 \%$ & $159 \%$ & $103 \%$ & $111 \%$ \\
\hline $\mathbf{1 2 .}$ & śląskie & $100 \%$ & $127 \%$ & $128 \%$ & $106 \%$ & $112 \%$ \\
\hline $\mathbf{1 3 .}$ & świętokrzyskie & $100 \%$ & $105 \%$ & $132 \%$ & $109 \%$ & $111 \%$ \\
\hline $\mathbf{1 4 .}$ & warmińsko-mazurskie & $100 \%$ & $128 \%$ & $194 \%$ & $101 \%$ & $111 \%$ \\
\hline $\mathbf{1 5 .}$ & wielkopolskie & $100 \%$ & $101 \%$ & $130 \%$ & $105 \%$ & $110 \%$ \\
\hline $\mathbf{1 6 .}$ & zachodniopomorskie & $100 \%$ & $129 \%$ & $155 \%$ & $104 \%$ & $112 \%$ \\
\hline
\end{tabular}

Analyzing the dynamics of costs by type in individual voivodeships, one can notice that the sum of the incurred costs changed. The largest increase in cost dynamics was recorded in Lubuskie Province in 2016 compared to 2015. It remained high in later years. In 2017, each of the provinces experienced a significant increase in generic costs compared to the previous year. 
Table 4. Share of generic costs incurred by Tax Administration Chambers in 16 provinces in collected taxes on the territory of each province in 2015-2019 in \% (own calculations)

\begin{tabular}{|c|c|c|c|c|c|c|}
\hline Lp. & Województwo & $\mathbf{2 0 1 5}$ & $\mathbf{2 0 1 6}$ & $\mathbf{2 0 1 7}$ & $\mathbf{2 0 1 8}$ & $\mathbf{2 0 1 9}$ \\
\hline $\mathbf{1 .}$ & Dolnośląskie & $1.48 \%$ & $1.77 \%$ & $1.85 \%$ & $1.86 \%$ & $2.05 \%$ \\
\hline $\mathbf{2 .}$ & Kujawsko-pomorskie & $3.26 \%$ & $2.69 \%$ & $3.30 \%$ & $2.92 \%$ & $3.02 \%$ \\
\hline $\mathbf{3 .}$ & Lubelskie & $0.55 \%$ & $2.95 \%$ & $5.60 \%$ & $5.50 \%$ & $5.77 \%$ \\
\hline $\mathbf{4 .}$ & Lubuskie & $4.90 \%$ & $7.14 \%$ & $9.02 \%$ & $8.62 \%$ & $11.07 \%$ \\
\hline $\mathbf{5 .}$ & Łódzkie & $1.56 \%$ & $1.77 \%$ & $2.03 \%$ & $1.94 \%$ & $2.09 \%$ \\
\hline $\mathbf{6 .}$ & Małopolskie & $1.24 \%$ & $1.52 \%$ & $0.45 \%$ & $0.50 \%$ & $0.54 \%$ \\
\hline $\mathbf{7 .}$ & Mazowieckie & $0.49 \%$ & $0.55 \%$ & $0.64 \%$ & $0.65 \%$ & $0.67 \%$ \\
\hline $\mathbf{8 .}$ & Opolskie & $1.75 \%$ & $2.05 \%$ & $2.50 \%$ & $2.88 \%$ & $3.16 \%$ \\
\hline $\mathbf{9 .}$ & Podkarpackie & $2.70 \%$ & $2.65 \%$ & $3.90 \%$ & $3.54 \%$ & $4.04 \%$ \\
\hline $\mathbf{1 0 .}$ & Podlaskie & $2.79 \%$ & $3.41 \%$ & $5.66 \%$ & $5.76 \%$ & $5.83 \%$ \\
\hline $\mathbf{1 1 .}$ & Pomorskie & $1.24 \%$ & $1.34 \%$ & $1.88 \%$ & $1.62 \%$ & $1.62 \%$ \\
\hline $\mathbf{1 2 .}$ & Śląskie & $1.72 \%$ & $2.08 \%$ & $2.05 \%$ & $1.86 \%$ & $1.90 \%$ \\
\hline $\mathbf{1 3 .}$ & Świętokrzyskie & $3.46 \%$ & $3.18 \%$ & $3.55 \%$ & $3.41 \%$ & $3.30 \%$ \\
\hline $\mathbf{1 4 .}$ & Warmińsko-mazurskie & $3.14 \%$ & $4.26 \%$ & $5.85 \%$ & $5.40 \%$ & $5.78 \%$ \\
\hline $\mathbf{1 5 .}$ & Wielkopolskie & $1.50 \%$ & $1.42 \%$ & $1.58 \%$ & $1.49 \%$ & $1.54 \%$ \\
\hline $\mathbf{1 6 .}$ & Zachodniopomorskie & $3.08 \%$ & $3.84 \%$ & $5.69 \%$ & $5.26 \%$ & $5.08 \%$ \\
\hline
\end{tabular}

The share of generic costs in collected taxes should oscillate below $2 \%$, as it happens in developed economies. In 2015-2019, the calculated indicator in Table 4 remained below 2\% in the provinces of Dolnośląskie, Łódzkie, Małopolskie, Mazowieckie, Pomorskie, Śląskie and Wielkopolskie. In the remaining voivodeships the share of costs was significantly higher (above $2 \%$ ). In the case of voivodeships that operate along external state borders, there may be a situation of reimbursement of goods and services tax (in connection with international sales taxed at a $0 \%$ VAT rate), which in effect will reduce the total tax revenue.

The calculated indicators presented in the context of the hypothesis allow stating that it has been verified positively. Each of the 16 voivodeships in Poland was characterized by a different ratio of the share of generic costs incurred by the Tax Administration Chambers in collected taxes in each voivodeship. Therefore, it can be concluded that in administrative units such as voivodeships costs are incurred in a different amount.

\section{Conclusions}

The analysis showed that the topic of the cost of tax collection is very important from the point of view of the public finance sector and its efficiency. The differences in the calculated indicators of the cost of tax collection in the 16 voivodeships result primarily from the different value of the taxes collected and the type of costs incurred. The calculated indicators in Table 4 for each of the provinces allow to draw the conclusion that there are provinces in which it is necessary to take action to reduce costs, because the incurred costs by type are disproportionate to the recorded tax revenue. The lowest tax collection costs were in Mazowieckie, Wielkopolskie, Śląskie and Małopolskie voivodeships. Such a low ratio results from the fact that the highest number of taxpayers, both legal entities and natural persons, is 
registered in the above mentioned voivodeships. Consequently, tax revenues are higher than in other provinces. On the other hand, in the eastern voivodeships (lubelskie, podkarpackie, podlaskie) the indicator of the share of costs by type in the tax revenue ranged from $2.65 \%$ to $11.07 \%$. The level of this indicator, although higher than in other provinces, does not prove that high collection costs are incurred. This is due to the fact that tax revenues in the eastern border region are reduced by goods and services tax refunds due to export sales, which are taxed at a $0 \%$ rate. Thus, the indicator will be higher than in other Polish voivodeships. Summing up the subject of costs of tax collection in individual provinces of Poland, it should be stated that these costs will always vary. This is mainly due to the specificity of tax administration activities in all provinces.

\section{References}

Franek, S., \& Adamczyk, A. (2017). Ocena systemów podatkowych państw Unii Europejskiej w świetle wypełniania zasad podatkowych. Annales Universitatis Mariae Curie-Skłodowska, sectio H-Oeconomia, 51(4).

Furman, W. (2011). Kontrolna funkcja rachunkowości podatkowej. In B. Micherda (Ed.), Wspótczesne aspekty realizacji kontrolnej funkcji rachunkowości (pp. 249-258). Warszawa Difin.

Furman, Ł. (2019). Efektywny system poboru podatków. CeDeWu.

Konopka, K. (2021). Wynagrodzenie biegłego sądowego. In A. Baryłka (Ed.), Poradnik biegłego sadowego (pp. 171197). CRB.

Smith, A. (2012). Badania nad natura i przyczynami bogactwa narodów, Tom 1. Wydawnictwo Naukowe PWN.

Neumark, F. (1970). Grundsätze der Besteuerung in Vergangenheit und Gegenwart. Wiesbaden.

Nowak, A. (2007a). Współczesne zasady podatkowe. In B. Fiedor, \& J. Rymarczyk (Eds.), Ekonomia $i$ międzynarodowe stosunki gospodarcze (pp. 14-15), Wydawnictwo Akademii Ekonomicznej im. Oskara Langego we Wrocławiu.

Nowak, A. (2007b). Współczesne zasady podatkowe. In M. Stawicka, \& M. Kędzierska (Eds.), Wydatki publiczne a rozwój. Wydawnictwo Akademii Ekonomicznej im. O. Langego we Wrocławiu.

Sosnowski, M. (2012). Znaczenie zasad podatkowych dla systemu podatkowego. Zeszyty Naukowe Uniwersytetu Szczecińskiego, 108, 60-61.

Turner, J., Smith, M., \& Gurd, B. (1998). Recognising the Pitfalls in Tax Compliance Costs Research. Revenue Law Journal, 8.

Żak, D. (2011). Rozwój elektronicznej administracji publicznej w Polsce. In J. Zieliński (Ed.), Rola informatyki w naukach ekonomicznych i społecznych. Innowacje i implikacje interdyscyplinarne (pp. 203-217). 